\title{
ADARs and the Balance Game between Virus Infection and Innate Immune Cell Response
}

\author{
Sara Tomaselli1*, Federica Galeano ${ }^{1 *}$, Franco \\ Locatelli1,2 and Angela Gallo $^{1}$
}

${ }^{1}$ Department of Pediatric Oncohaematology, Bambino Gesù Children's Hospital IRCCS, Viale di San Paolo, 15 00146 Rome, Italy

2Department of Pediatric Science, Università di Pavia, Strada Nuova 65, 27100 Pavia, Italy

*Equal contributors

Corresponding author: angela.gallo@opbg.net

DOI: http://dx.doi.org/10.21775/cimb.017.037

\begin{abstract}
All viruses that have dsRNA structures at any stages of their life cycle may potentially undergo RNA editing events mediated by ADAR enzymes. Indeed, an increasing number of studies that describe A-to-I sequence changes in viral genomes and/or transcripts, consistent with ADAR deaminase activity, has been reported so far. These modifications can appear as either hyperediting or specific RNA editing events in viral dsRNAs.

It is now well established that ADAR enzymes can affect viral life cycles in an editing-dependent and independent manner, with ADARs acting as pro- or antiviral factors. Despite the discovery of editing events in viral RNAs dates back to thirty years ago, the biological consequences of A-to-I changes during viral infection is still far to be completely elucidated. In this review, past and recent studies on the importance of ADAR enzymes on
\end{abstract} several viruses will be examined.

\section{Introduction}

The number of virus families as well as their different replication strategies is countless. However, viruses require host cellular machineries for their RNA and protein synthesis. The presence of viral RNA molecules inside the host cell is the starting point common to all viruses. Viral genomes/transcripts with double-stranded RNA (dsRNA) structures can be recognized by the family of adenosine deaminases acting on dsRNA (ADARs). The ADAR enzymes deaminate Adenosines (A) changing them into Inosines (I). Inosine is recognized as Guanosine (G) by the splicing and translation machineries, with important physiological consequences. Therefore, viral dsRNAs modified by ADAR enzymes may introduce an additional layer of complexity in the viral life cycle. The first study reporting A-to-I/G changes in virus dates back to 1984 , when O'Hara and co-authors described these events in the RNA of vesicular stomatitis virus (VSV) (O'Hara et al., 1984). Thenceforth, A-to-I RNA editing was observed in several viral RNAs.

Three ADAR enzymes are present in mammals (ADAR1-3), with only ADAR1 and ADAR2 showing deaminase activity. These three enzymes are RNA-binding proteins organized with a similar domain structure, with the deaminase catalytic domain (DM) at the C-terminus and two or three dsRNA-binding domains (RBDs) at the $\mathrm{N}$ terminus (Gallo and Locatelli, 2011; Tomaselli et al., 2014). ADARs can modify viral dsRNAs at selective site/s (i.e. in HDV) or at multiple sites by editing at up to $50 \%$ of all adenosine residues of viral transcripts, a phenomenon named as hyperediting (i.e. in MV).

Both ADAR1 (the full-length p150 and the N-terminally truncated p110 isoform) and ADAR2 can play an important role in editing viral dsRNAs. Of note, the long form of ADAR1 ( 150 ) localizes in both cytoplasm and nucleus, whilst ADAR1 p110 and ADAR2 are mainly nuclear proteins. As most viruses replicate in the cytoplasm, the cytoplasmic ADAR1 p150 is likely the best candidate for editing most viruses. The observation that interferons (IFNs) induce ADAR1 p150 expression (Patterson and Samuel, 1995) raised the hypothesis that this specific isoform may play an important role in host defence mechanisms against viral infection. Moreover, the observation that ADAR1 p150 physically interacts with the nuclear factor 90 (NF90) proteins (such as NF110, NF90 and NF45), with a consequent activation of the cellular antiviral cascade and IFN- $\beta$ induction (Nie et al., 2005) further supported this hypothesis. The notion that A-to-I RNA editing can play an antiviral role came also from the observation that several viral RNA genomes and transcripts show hyperediting during persistent viral infections profoundly mutating viral RNAs (Samuel, 2011).

Though, different lines of evidences indicate that ADAR enzymes do not play only an antiviral role but they can act also as pro-viral proteins. Curiously, ADAR1 has emerged as a replication enhancer of many viruses (HIV-1, MV, VSV, HDV) during acute infections (Clerzius et al., 2011). This proviral role of ADAR1 appears to occur via two mechanisms: by editing viral substrates (as example, Wong and Lazinski, 2002) and/or by inhibiting the doublestranded RNA-dependent protein kinase (PKR) in an editing-independent manner (as example, George et al., 2009; Clerzius et al., 2011; Pfaller et al., 2011). The two mechanisms can act independently in order to increase viral replication in the host cell.

PKR was first recognized as a $68-k D a$ protein induced by IFN (Meurs et al., 1990). It is a serine/threonine kinase, whose activation is a critical component of the antiviral cell defence and cell growth pathways (Garcia et al., 2006). The two dsRBDs of PKR act as a dsRNA-sensor against pathogenic invasions. The presence of exogenous/ abundant dsRNAs in a cell promotes dimerization and activation of PKR that, through the C-terminal catalytic kinase domain, phosphorylates a variety of substrates, such as the alpha subunit of the translation eukaryotic initiation factor 2 (elF-2a) (Lemaire et al., 2008). Phosphorylation of elF-2 $\alpha$ on serine 51 negatively alters 
the efficiency of translation initiation, reducing cellular as well as viral protein synthesis (Sadler and Williams, 2007). Viruses have developed different mechanisms to counteract PKR antiviral activity that include the expression of viral dsRNAs or proteins that can i) suppress PKR activity by direct binding, ii) induce PKR degradation, iii) promote the elF-2 $\alpha$ dephosphorylation (Gale and Katze, 1998). Viruses have also acquired the ability to exploit host cellular factors (such as PACT, TRBP and ADAR1) in order to inactivate PKR (Clerzius et al., 2011). For example, ADAR1 can inhibit PKR activity in several acute infections resulting in an enhanced viral replication of the vesicular stomatitis virus (VSV), measles virus (MV) and human immunodeficiency virus type 1 (HIV-1) (for a review, see Samuel, 2011). Specifically, during VSV infection, ADAR1 p150 can bind the first dsRBD of PKR, reducing PKR kinase activity and suppressing the elF-2 $\alpha$ phosphorylation by an editing-independent mechanism (Nie et al., 2007).

The existence of IFN-inducible RNA-binding proteins (ADAR1 p150 and PKR) with opposite effects could seem puzzling, but highlights the presence of a complex and finetuned balance between viral spread and host cell defence. Moreover, for some viruses ADARs could act in both a proviral and antiviral manner, depending on the cellular/ time context (i.e. MV, HDV).
Herein, we gather the current knowledge of A-to-I RNA editing and viruses, classified according to their family and genome type (circular dsDNA, linear dsDNA, ss(+)RNA and ss(-)RNA) (Table 1 and Figure 1)

\section{Polyomaviridae}

Murine polyoma virus (MPyV)

The members of the Polyomaviridae family are naked viruses, with an icosahedric capsid and a small circular double-stranded DNA (dsDNA) genome ( $\sim \mathrm{Kbp})$. Polyoma viruses can infect both animals and humans, and are often associated with the development of tumours.

The polyoma virus life cycle is divided in two distinct phases: the early phase, which occurs immediately after the infection and before viral replication, and the late phase, which begins after the onset of viral genome replication. The early and late genes are transcribed bidirectionally from opposite strands of the viral genome.

During the viral life cycle, there is an accurate regulation of the early-late phase 'switch'. At early times after infection, the early transcription units accumulate (late:early ratio of 1:10); however, after viral DNA synthesis, the late-genes increase (late:early ratio of 50:1) (Gu et al., 2009). This temporal transition is independent from changes in promoter efficiency (Hyde-DeRuyscher and

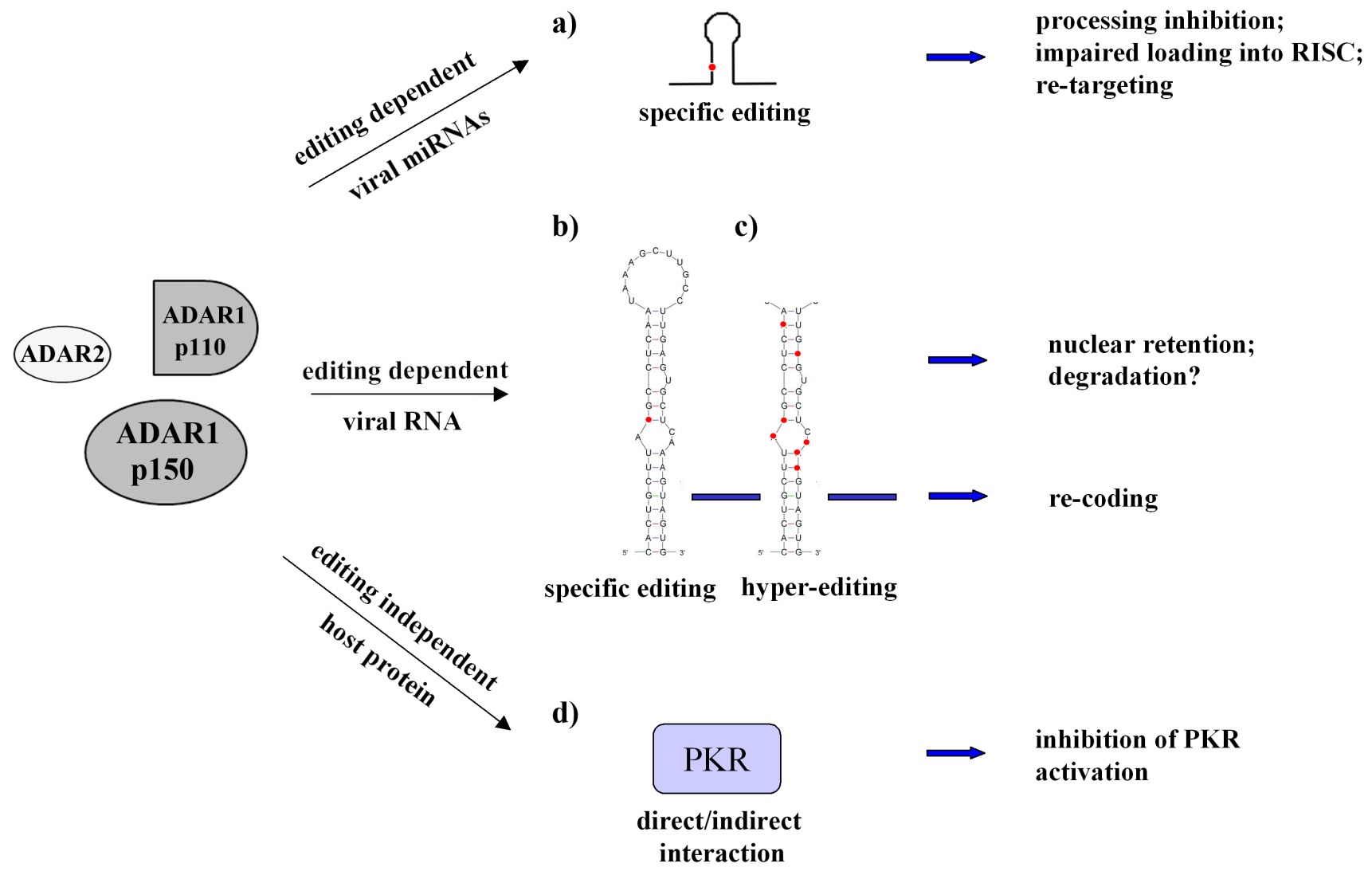

Figure 1. Possible ADAR-mediate effects after viral infection: (a) editing of viral miRNAs; editing of viral transcripts (b) at specific sites (such as 5'-UTR of HIV) or (c) at multiple non-specific sites (hyperediting); (d) direct/indirect interaction with host proteins (such as PKR). 
Table 1. Viruses undergoing RNA editing events by ADARs. $\quad \mathrm{ND}=$ not determined

\begin{tabular}{|c|c|c|c|c|c|c|}
\hline Family/Genus & Virus & Genome & Host & Editing in viral RNAs & ADAR enzyme & $\begin{array}{l}\text { Overall ADAR } \\
\text { effect }\end{array}$ \\
\hline Polyomaviridae & MpyV & circular dsDNA & mouse & hyperediting & $\begin{array}{l}\text { Ad1 } \\
\text { Ad1 p110 }\end{array}$ & $\begin{array}{l}\text { proviral } \\
\text { antiviral }\end{array}$ \\
\hline Herpesviridae & $\begin{array}{l}\text { EBV } \\
\text { KSHV }\end{array}$ & $\begin{array}{l}\text { linear dsDNA } \\
\text { linear dsDNA }\end{array}$ & $\begin{array}{l}\text { Humans } \\
\text { humans }\end{array}$ & $\begin{array}{l}\text { pri-miR-BART } 6 \text { and -BART3 } \\
\text { kaposin A and miR-K10 }\end{array}$ & $\begin{array}{l}\text { Ad1 (?) } \\
\text { Ad1 p110 }\end{array}$ & $\begin{array}{l}\text { viral latency latent/ } \\
\text { lytic switch }\end{array}$ \\
\hline Flaviviridae & $\begin{array}{l}\mathrm{HCV} \\
\text { DENV } \\
\text { BVDV }\end{array}$ & $\begin{array}{l}\text { ss(+)RNA } \\
\text { ss(+)RNA } \\
\text { ss(+)RNA }\end{array}$ & $\begin{array}{l}\text { humans } \\
\text { humans } \\
\text { mammals }\end{array}$ & $\begin{array}{l}\text { hyperediting } \\
\text { ND } \\
\text { ND }\end{array}$ & $\begin{array}{l}\text { Ad1 p150 } \\
\text { Ad1 } \\
\text { ND }\end{array}$ & $\begin{array}{l}\text { antiviral } \\
\text { proviral } \\
\text { antiviral }\end{array}$ \\
\hline Retroviridae & $\begin{array}{l}\text { RAV-1 } \\
\text { ALV } \\
\text { HTLV-2 } \\
\text { STLV-3 } \\
\text { HIV-1 }\end{array}$ & $\begin{array}{l}\text { ss(+)RNA } \\
\text { ss(+)RNA } \\
\text { ss(+)RNA } \\
\text { ss(+)RNA } \\
\text { ss(+)RNA }\end{array}$ & $\begin{array}{l}\text { birds } \\
\text { birds } \\
\text { human } \\
\text { monkey } \\
\text { humans }\end{array}$ & $\begin{array}{l}\text { hyperediting } \\
\text { hyperediting } \\
\text { hyperediting } \\
\text { hyperediting } \\
\text { 5'UTR, Tat, Rev, Env (RRE) }\end{array}$ & $\begin{array}{l}\text { ND } \\
\text { ND } \\
\text { Ad1 } \\
\text { Ad1 } \\
\text { Ad1 and Ad2 } \\
\text { Ad1 }\end{array}$ & $\begin{array}{l}\text { ND } \\
\text { ND } \\
\text { ND } \\
\text { ND } \\
\text { proviral } \\
\text { antiviral }\end{array}$ \\
\hline Arenaviridae & LCMV & ss(-)RNA & mammals & hyperediting & Ad1 p150 & antiviral (?) \\
\hline Bunyaviridae & RVFV & ss(-)RNA & humans & hyperediting & ND & ND \\
\hline Deltavirus & $\mathrm{HDV}$ & ss(-)RNA & humans & Amber/W & Ad1 p110 & proviral \\
\hline Orthomyxoviridae & Influenza A virus & ss(-)RNA & $\begin{array}{l}\text { mammals, } \\
\text { birds }\end{array}$ & hyperediting & Ad1 p150 & $\begin{array}{l}\text { antiviral } \\
\text { proviral }\end{array}$ \\
\hline Paramyxoviridae & $\begin{array}{l}\text { MV } \\
\text { HRSV } \\
\text { HPIV3 } \\
\text { HMPV }\end{array}$ & $\begin{array}{l}\text { ss(-)RNA } \\
\text { ss(-)RNA } \\
\text { ss(-)RNA } \\
\text { ss(-)RNA }\end{array}$ & $\begin{array}{l}\text { humans } \\
\text { humans } \\
\text { humans } \\
\text { humans }\end{array}$ & $\begin{array}{l}\text { hyperediting } \\
\text { multiple editing in } \mathrm{G} \text { protein } \\
\text { hyperediting } \\
\text { hyperediting }\end{array}$ & $\begin{array}{l}\text { Ad1 p150 } \\
\text { Ad1 } \\
\text { ND } \\
\text { ND } \\
\text { Ad1 (?) }\end{array}$ & $\begin{array}{l}\text { antiviral } \\
\text { proviral } \\
\text { proviral } \\
\text { ND } \\
\text { ND }\end{array}$ \\
\hline Rabdoviridae & $\begin{array}{l}\text { VSV } \\
\text { Drosophila sigma virus }\end{array}$ & ss(-)RNA & $\begin{array}{l}\text { plansts, } \\
\text { insects, } \\
\text { mammals } \\
\text { drosophila }\end{array}$ & multiple editing & Ad1 p150 & $\begin{array}{l}\text { proviral } \\
\text { no effect } \\
\text { ND }\end{array}$ \\
\hline
\end{tabular}

Carmichael, 1988; Liu and Carmichael, 1993) and resulted to be regulated post-transcriptionally by, at least in part, RNA editing processes (Kumar and Carmichael, 1997; Gu et al., 2009). Specifically, at late times due to a polyadenylation defect the late gene transcripts generate multimeric RNAs that carry embedded regions with sequence complementary to the early RNAs, thus creating dsRNA structures (Liu and Carmichael, 1994). Analysis of the early strand RNAs, isolated in the late phase of infection, revealed widespread nucleotide modifications, consistent with adenosine deamination mediated by ADARs (Kumar and Carmichael, 1997). About $40-60 \%$ of adenosines in early-strand RNAs were modified to inosines/guanosines. This A-to-I hyperediting seems to be responsible for the retention of the modified early-strand RNAs in the nucleus preventing their translation in the late phase of infection (Kumar and Carmichael, 1997). Evidence has emerged that nuclear retention of promiscuously edited RNAs is a general phenomenon involving a multi-protein complex that anchor hyperedited RNAs to the nuclear matrix, thus keeping them away from the translational machinery (Zhang and Carmichael, 2001). Later studies demonstrated that the polyadenilation defect of the late transcripts is also due to RNA editing (Gu et al., 2006, 2009).
The functional significance of RNA editing in regulating the polyoma virus life cycle has been further analysed in MPyV-permissive NIH3T3 (mouse embryonic fibroblast) cells down-expressing Adar1. The authors observed that Adar1 reduction lead to a defective early-to-late switch pattern of the virus (Gu et al., 2009).

George and Samuel further explored the role of ADARs in MPyV infection using mouse embryonic fibroblast (MEF) cells isolated from Adar1 or Adar2 knockout mice (George and Samuel, 2011). The hypothesis was that if ADAR-mediated hyperediting was a critical component for the gene expression regulation in MPyV, then the genetic depletion of either Adar1 or Adar2 should restrict virus growth. Actually, this was not observed: viral growth (and viral protein expression) was comparable between Adar1 ${ }^{-1-}$ and Adar2 ${ }^{-1-}$ MEF cells and, unexpectedly, more efficient than the wild-type cells. The authors supposed that the formation of dsRNA structures, rather than the editing events, is the critical component for the viral gene regulation. The authors also reported that only the absence of Adar1, and in particular of its short isoform p110, enhanced MPyV-induced cytotoxicity of MEF cells, independently by its editing activity. The authors concluded that both Adar1 and Adar2 repress MPyV growth 
in MEFs, whereas only Adar1 p110 drives cytotoxicity in MEF cells infected by MPyV (George and Samuel, 2011).

Taken together, these data highlight the crucial multiple roles played by ADAR proteins in polyoma virus infection.

\section{Herpesviridae}

Herpesviridae family members are composed of a linear dsDNA genome, an icosahedric capsid, a tegument containing viral proteins and an envelope. All herpesviruses have two distinct life cycles: lytic and latent replication phases. During acute (lytic) infection, the virus sequentially expresses its entire repertoire of genes. The symptomatic infection is characterized by an enhanced replication and production of virions that spread infection from cell to cell. After a self-limited period of lytic infection, in some specific host cells the virus can enter into a latent state expressing only selected genes, evading host immune surveillance mechanisms and establishing an asymptomatic, persistent infection.

According to the site of latency, herpesviruses are divided into three subfamilies: $\alpha, \beta$ and $\gamma$. The latter includes the Epstein-Barr virus (HHV-4) and the Kaposi's sarcoma-associated herpesvirus (HHV-8), with B cells as sites for the latent phase of both viruses. Both of these viruses encode RNA transcripts that undergo highly siteselective A-to-I editing events.

\section{Epstein-Barr virus (EBV or HHV-4)}

Epstein-Barr virus (EBV), also known as human herpesvirus 4 (HHV-4), has as its exclusive primary cell targets the human B cells and epithelial cells. EBV causes infectious mononucleosis during its lytic infection; interestingly, EBV latent viral infection is associated with a variety of lymphoma (Burkitt lymphoma, Hodgkin disease) and some epithelial cancers (nasopharyngeal carcinoma). EBV has a linear dsDNA genome of $172 \mathrm{Kbp}$ with about 100 genes, of which only 9-11 are transcribed during virus latency. Three different types of latency have been identified (I-III) and the transition from lytic infection to distinctive latency states is finely regulated by both viral transcripts and viral microRNAs (miRNAs). Indeed, EBV encodes for more than 20 miRNAs, from two primary transcripts (BHRF1 and BART), implicated in the attenuation of host antiviral immune response and in the regulation of the lytic/latent transition (Cullen, 2009; Skalsky and Cullen, 2010). Among the EBV miRNAs, four primary miRNAs showed site-specific A-to-I editing events: pri-miR-BHRF1-1, pri-miR-BART6, pri-miR-BART8 and primiR-BART16 (lizasa et al., 2010). It has been shown that the pri-miR-BART6 carries editing at the +20 site of the $3 p$ strand in three latently EBV-infected cell lines (lizasa et al., 2010). Western blotting analysis in these cells showed an abundant expression of ADAR1 p150 and p110 and a lack of ADAR2, suggesting that ADAR1 may be the candidate enzyme responsible for these editing events. To investigate the effects of editing at the +20 site of miR-BART6, the authors analysed its maturation process. Interestingly, a combination of A-to-I editing at the +20 site plus a deletion of three $U$ residues in this miRNA precursor was able to completely inhibit Drosha cleavage, with a total depletion of the corresponding pre- and mature miRNA. However, +20 editing site alone (without the $3 \mathrm{bp}$ deletion) did not affect
miR-BART6 biogenesis, but decreased the loading of the edited miR-BART6-5p onto the microRNA-induced silencing complex (miRISC) (lizasa et al., 2010). Remarkably, this is the first study reporting A-to-I RNA editing that affects miRISC loading (lizasa et al., 2010).

Interestingly, the wild-type miR-BART6 controls viral proteins required for lytic replication and for the transition of the type I-II to type III latency; moreover, it can target the host-cell Dicer transcript, with important consequences for both host and viral RNA targets (lizasa et al., 2010). Indeed, miR-BART6, by targeting Dicer, also downregulates host miRNAs necessary for the immune response (lizasa et al., 2010).

A recent work reported four A-to-I editing sites within the pri-miR-BART3, in nasopharyngeal carcinoma tissues and cell line (C666-1) (Lei et al., 2013). The authors demonstrated that both the biogenesis and the targeting of the mature miR-BART3 were affected by these editing events. Specifically, an editing site within the seed region of miR-BART3-5p, significantly compromises its silencing activity (Lei et al., 2013), whilst another editing event, present within the seed of miR-BART3-3p, reduces miRNA biogenesis (Lei et al., 2013).

In conclusion, A-to-I RNA editing may represent a posttranscriptional mechanism to modulate both the expression and the activity of viral and host miRNAs during EBVinfection.

Kaposi's sarcoma-associated herpesvirus (KSHV or HHV-8)

Kaposi's sarcoma-associated herpesvirus (KSHV), also named as human herpesvirus 8 (HHV-8), is one of the seven currently known human oncoviruses (together with HCV, HBV, HTLV-1, HPV, HIV, EBV) (Talbot and Crawford, 2004). KSHV has a linear dsDNA genome of about $160-170 \mathrm{Kbp}$. After infection, the genome enters into the cell as episomal DNA and replicates itself using the cellular replication machinery. Usually, the virus remains in a latent state expressing a limited number of genes, without integrating into host chromosomes and with no virion production. However, various signals, such as inflammation, may provoke the virus to enter into lytic replication. Epigenetic regulation seems to be essential for the activation/inactivation of latent genes (Ohsaki and Ueda, 2012). Interestingly, most lymphoma tumour cells only show evidence of latent infection, with a restricted gene expression pattern, such as the latent nuclear antigen 1 (LNA-1). This protein is able to interact with both the p53 and the retinoblastoma (RB1) proteins and, for this ability, it is directly involved in the tumorigenic process (Cathomas, 2003). Indeed, KSHV is the etiologic agent responsible for the Kaposi's sarcoma (KS), a cancer that develops from the endothelium of lymphatic or blood vessels. Additionally, this virus is also closely associated with other tumors (such as primary effusion lymphoma, PEL).

The K12 (kaposin) RNA transcript is induced during Iytic viral replication but is abundantly expressed during the latent phase of KSHV infection. K12 transcript gives rise to three protein isoforms (kaposin A, B and C), thanks to different translation starting codons, and to the miR-K10 (Sadler et al., 1999). Specifically, the kaposin A open reading frame (ORF) includes kaposin A mRNA and the 
miR-K10, both of which have a tumorigenic potential (Muralidhar et al., 1998, 2000; Damania, 2004).

A specific A-to-I nucleotide change has been reported (at position 117,990 of the viral transcript isolated from PEL tumors), affecting both the coding sequence of the kaposin A protein (changing the serine to a glycine at amino acid 38 ) and the seed sequence of the mature miR-K10 (Pfeffer et al., 2005; Gandy et al., 2007). ADAR1 p110 is able to edit the K12 transcript (Gandy et al., 2007); however, ADAR2 and ADAR1 p150 involvement were not tested. Remarkably, the authors observed that this A-to-I editing has a functional significance, with a key role in the replication strategy and tumorigenic potential of KSHV. PEL cancer cells (latently infected by KSHV) show unedited K12 transcripts; whilst editing within $\mathrm{K} 12$ increases during the Iytic viral phase and seems to decrease the oncogenic potential of KSHV (Gandy et al., 2007).

Recently, by a systematic genome-wide survey of KSHV transcriptome throughout the lytic cycle of the virus, Arias et al., (2014) confirmed the previously reported A-to$\mathrm{G}$ transition within the kaposin transcript (Gandy et al., 2007), without finding novel A-to-G editing events.

Interestingly, they found that the relative amount of edited kaposin transcripts accumulates throughout the viral lytic cycle progression, concomitantly with the increasing levels of ADAR1 protein isoforms (Arias et al., 2014).

To date the A-to-I changes within EBV pri-miRBART3/6 and KSHV miR-K10 are the only examples of ADAR-mediated editing events of viral miRNAs.

\section{Flaviviridae}

The name Flaviviridae (from the Latin flavus, yellow) is due to the first isolated member of this family, the yellow fever virus. The members of Flaviviridae family are singlestranded positive sense RNA (ss(+)RNA) viruses, provided with an envelope and an icosahedric capsid (Choo et al., 1991). The genome consists of a single ORF flanked by 5'and 3'- untranslated regions, which are essential for efficient translation and replication of viral genome (Ito et al., 1998). This family contains 3 genera: Hepacivirus (an example is the HCV), Flavivirus (an example is the DENV) and Pestivirus (an example is the BVDV) (Rice, 1996).

\section{Hepatitis $C$ virus (HCV)}

Hepatitis C virus (HCV) was first isolated in 1989 as a non$A$, non-B hepatitis agent (Choo et al., 1989). The virus is transmitted parentally (blood-blood contact), sexually and vertically (from the mother to child), with more than 170 million people estimated to be infected (Raza et al., 2007). $\mathrm{HCV}$ is recognized as the major cause of acute and chronic liver disease worldwide (Clement et al., 2009); indeed, the acute infection becomes lifelong persistent in more than $80 \%$ of cases and may result in chronic liver disease, cirrhosis and hepatocellular carcinoma (Levrero, 2006). The HCV genome consists of an uncapped, ss(+)RNA molecule of $9.6 \mathrm{Kbp}$, characterized by the presence of conserved RNA secondary structures (Tuplin et al., 2002; Simmonds, 2004).

The first work reporting A-to-I editing events in the HCV genome came from Taylor et al. in 2005. The authors detected random A-to-I changes in viral RNA isolated from IFN-treated Huh7 cells (hepatocyte derived cellular carcinoma cell line) stably transfected with HCV RNA replicon (Taylor et al., 2005). By a silencing approach, the authors demonstrated that this hyperediting phenomenon is catalysed exclusively by ADAR 1 and that the knockdown of this enzyme stimulates replicon expression in these cells. It has been also shown that the ADAR1 p150 isoform is strongly and specifically upregulated in HCV-infected Huh7.5 cells (Alisi et al., 2011), further confirming a role for this enzyme in HCV infection.

Recently, Li et al. demonstrated that, among other, ADAR1 (not clear if the p150 or p110 isoform, or both) binds to the 5'-terminal sequence of the hepatitis $C$ virus (HCV) positive-strand RNA genome, which is essential for viral replication. Despite so, the authors excluded a role of this enzyme in virus replication as shown by ADAR1 siRNA experiments (Li et al., 2014).

In conclusion, an antiviral role of ADAR1 in HCV infection can be likely stated. ADAR1 p150 editing activity may induce RNA degradation or mutations in viral RNA sequences, thus directly preventing HCV genome replication and viral protein synthesis. Further studies are needed to explore the meaning of ADAR binding to HCV genome and the possible effects over the host response.

\section{Dengue virus (DENV)}

Dengue virus (DENV), a member of the Flavivirus genus, causes the most common arthropod-borne viral infection among humans according to the World Health Organization (Iglesias and Gamarnik, 2011). The DENV genome consists of a ss(+)RNA molecule of $11 \mathrm{Kbp}$, carrying a single ORF translated into a long protein precursor, which is cleaved by host cell and viral proteases. The $\mathrm{NH}_{2}-$ terminal of the polyprotein encodes for 3 structural proteins, which are components of the mature viral particles, while the rest of DENV genome encodes for 7 non-structural proteins (NS1, NS2A, NS2B, NS3, NS4A, NS4B and NS5).

A recent work from de Chassey et al. (2013) showed that the Dengue virus NS3 protein, through its helicase domain, cooperatively interacts with ADAR1. The binding between these proteins enhances both the editing activity of ADAR1 and the viral replication. This finding gives a first insight towards a possible role of ADAR1 in DENV replication. However, more experiments should be performed in order to elucidate the mechanism of action of the enzyme and to identify the dsRNA targets involved (de Chassey et al., 2013).

\section{Bovine viral diarrhea virus (BVDV)}

Bovine viral diarrhea virus (BVDV) belongs to Pestiviruses, important animal pathogens and causative agents of livestock diseases worldwide. BVDV has a ss(+)RNA genome of about $12.3 \mathrm{Kbp}$, encoding for structural and nonstructural proteins (Lindenbach and Rice 2001; Becher and Thiel 2002).

Recently, Akashi and co-workers searched for the interacting partners of BVDV NS4A, a cofactor of NS3 protease (Mohamed et al., 2014). They demonstrated that NS4A interacts with ADAR enzyme upon infection and that the binding occurs through the $\mathrm{N}$-domain of the viral protein. Moreover, the authors showed that ADAR exerts an inhibitory effect on BVDV replication, speculating that its 
antiviral role may be due to hyperediting of yet unknown dsRNA substrates, which are -in turn- cleaved by host cell endonucleases and so eliminated (Mohamed et al., 2014).

\section{Retroviridae}

The members of the Retroviridae family consist of enveloped virions containing two copies of RNA genome, the reverse transcriptase (RT) and the integrase proteins that are essential for the viral replication. The retroviral genome consists of two ss(+)RNA molecules (about 7-10 Kbp long), with a 5' Cap and $3^{\prime}$ poly $(A)$ end sequences, that can be reverse transcribed by the viral RT in the cytoplasm of the cell-host and, then, randomly integrated into the host cell genome by the viral integrase enzyme. At this point, the virus is called provirus and undergoes the usual transcription and translation processes to express viral genes (gag, pol, env), using the machineries of the host cell. The viral RNA is characterized at the 5'- and 3'-ends by LTRs (Long Terminal Repeats). Once the provirus has been integrated, the LTR on the $5^{\prime}$-end serves as promoter for the entire retroviral genome, while the LTR at the 3 '-end provides for the viral RNA polyadenylation signal. Of note, all the signals required for gene expression are found in the LTRs: enhancer, promoter, transcription initiation (such as capping), transcription terminator and polyadenylation signal. Gag (group-specific antigen) codes for the core and the structural proteins, $\mathrm{pol}$ (polymerase) codes for the RT, protease and integrase, and env (envelope) codes for the retroviral coat proteins. Among all the genera, we will analyse Alpharetrovirus, Deltaretrovirus and Lentivirus (i.e. HIV-1).

Alpharetrovirus: rous-associated virus type 1 (RAV-1) and avian leukosis virus (ALV)

Sequence changes, probably due to ADARs activity, have been described for two alpharetroviruses: rous-associated virus type 1 (RAV-1) (Felder et al., 1994) and avian leukosis virus (ALV) (Hajjar and Linial, 1995).

The first hint that A-to-I RNA editing could have fundamental implications in retroviruses derives from Felder et al. (1994). Indeed, highly mutated U3 long viral terminal repeats (LTRs) were found, with $48 \%$ of Adenosines converted into Guanosines (Felder et al., 1994). These mutations were widespread in the U3 sequence, leading to changes in several viral regulatory elements. This hyperediting resulted in an inactive polyadenylation signal (PAS) of the 3' LTR, allowing readthrough transcription of downstream sequences (Felder et al., 1994).

One year later, an avian retroviral recombinant provirus was described to contain a 150-nt inverted repeat with about $50 \%$ of Adenosines mutated into Guanosines (Hajjar and Linial, 1995). The authors proposed that these changes were a possible result of ADAR activity leading to possible virus replication defect (Hajjar and Linial, 1995).

Nevertheless, at that time a dsRNA-modifying enzyme had been just hypothesized (Bass and Weintraub, 1988; Wagner et al., 1989) and additional studies were not carried out to demonstrate the real involvement of ADARs in RAV-1 and ALV hyperediting phenomena.

Deltaretrovirus: human T-cell leukemia virus type 2 (HTLV-2) and simian T-cell leukemia virus type 3 (STLV-3)
The deltaretrovirus group includes four human T-cell leukemia viruses (HTLVs), which infect humans, and four types of simian T-cell leukemia viruses (STLVs), which infect old world monkeys (Slattery et al., 1999). Using a particular PCR-based method (3DI-PCR) that allows the amplification of ADAR-edited RNAs (Suspene et al., 2008), Vartanian and collaborators discovered that both the HTLV-2 and STLV-3 RNA genomes undergo extensive Ato-G modifications in cells (Ko et al., 2012). However, when the authors looked for similar editing events in vivo, analysing PBMCs from HTLV-2 infected individuals, hyperedited sequences were not found (Ko et al., 2012).

\section{Human immunodeficiency virus type I (HIV-1)}

Human immunodeficiency virus type 1 (HIV-1) is a lentivirus discovered in 1983 (Barre-Sinoussi et al., 1983; Gallo et al., 1983). It is the causative agent of acquired immunodeficiency syndrome (AIDS) (Weiss, 1993), a severe and fatal disease characterized by progressive failure of the immune system. The primary targets of HIV-1 are the immune system components: T-cells, monocytes, macrophages and dendritic cells. The viral genome is composed of two ss(+)RNA (9749 bp long) that code for nine genes: in addition to the three major structural genes (gag, pol and env), there are other 'accessory' genes unique to HIV (the transactivators tat, rev, vpr and the regulators vif, nef, vpu). Within the HIV RNA, there are conserved secondary structures, such as the transactivating responsive (TAR) element, located within the LTR at the 5'- and 3'-ends, and the Rev response element (RRE), located within the env gene. These structures seem to be important for the HIV life cycle, by modulating the function of protease and reverse transcriptase (RT).

Brenda Bass's group provided the first evidence that Ato-I RNA editing occurs in HIV-1 (Sharmeen et al., 1991). The authors showed that the intramolecular TAR stem-loop structure is a substrate for A-to-I editing when injected into the nuclei of Xenopus laevis oocytes. In particular, 5-10\% adenosines of TAR sequence resulted to be converted to inosines, but only in the presence of Tat, a potent viral activator of HIV-1 gene expression (Sharmeen et al., 1991). Despite the biological role of these editing events was not established, this finding raised the question whether RNA editing within HIV-1 transcripts occurs also in HIV-1 infected T-cells and to which extent this may contribute to the different steps of the viral life cycle. The observation that ADAR1 mRNA and protein levels increased following HIV infection of primary T-cells supported the hypothesis that ADAR1 is involved in HIV-1 replication (Phuphuakrat et al., 2008; Clerzius et al., 2009). In particular, several studies provided evidence that HIV-1 takes advantage of ADAR1 for viral replication by editingdependent and -independent mechanisms (Phuphuakrat et al., 2008; Clerzius et al., 2009; Doria et al., 2009). Indeed, overexpression of ADAR1, but not of its catalytic inactive version, up-regulated p24 protein expression in producer cells (COS-7, 293T) (Phuphuakrat et al., 2008). Sitespecific A-to-G changes were found around the RRE region within the env gene (nucleotide positions 8164 to 8166 ) (Phuphuakrat et al., 2008). Strangely, no editing was found in TAR, as expected (Sharmeen et al., 1991). The biological significance of env editing was explored by 
creating a HIV-1 genome with the three site-specific edited sites. This mutant construct was expressed more efficiently than the wild-type, underscoring the proviral effect of the site-specific RNA editing in HIV-1 (Phuphuakrat et al., 2008).

Further studies dissected the mechanisms of ADAR1 proviral effect and the contribution of its editing activity, leading to partially discrepant conclusions. These works showed that, in contrast to the findings of Phuphuakrat et al. (2008), both the active and the inactive (E/A) form of ADAR1 strongly increase viral protein amount (such as gp120, p24 and Nef) in HIV-1 producer cells (Clerzius et al., 2009; Doria et al., 2009). However, the ADAR1mediated editing activity is crucial to increase the assembly/release of progeny virions and, most importantly, their infectious potential (Doria et al., 2009). These studies showed new editing events both in coding (Rev and Tat) and non-coding (5'UTR) regions of the viral RNA. Specifically, four out five editing events within the 5'UTR were located within the poly(A) signal (Doria et al., 2009). Rev and Tat sequences were found to be edited at six and one sites respectively, with five out of six editing events in the Rev sequence leading to amino acid changes in crucial regions for its regulative function (Doria et al., 2009). However, how these editing events mediate the effects observed on HIV-1 replication is still an open question that deserves additional investigations.

In addition to the editing-dependent effect of ADAR1 on HIV-1 replication, an editing-independent mechanism was also characterized by these studies. As previously mentioned, ADAR1 physically interacts with PKR, leading to PKR inactivation (Nie et al., 2007). The ADAR1mediated PKR inhibition is one of the mechanisms used by HIV-1 to impair the host antiviral response (Clerzius et al., 2009; Doria et al., 2009). Both the active and the inactive form of ADAR1 lead to reduced levels of phosphorylated PKR and its target elF-2 $\alpha$, which correlate with increased viral protein production (Clerzius et al., 2009; Doria et al., 2009). The ADAR1-mediated PKR suppression requires at least one Z-DNA binding domain (Z-DBD) and the three dsRNA binding domains (dsRBDs) of ADAR1, whilst the deaminase activity is not necessary (Clerzius et al., 2009).

However, additional mechanisms by which ADAR1 can positively modulate HIV-1 replication are highly likely to exist and have partially been dissected in a recent study by Gatignol's group (Clerzius et al., 2013). The authors found that, during HIV-1 replication, PACT forms a protein complex with PKR, TRBP and ADAR1 and that, in contrast to its previously described PKR activator role (Patel and Sen, 1998; Patel et al. 2000; Singh and Patel, 2012), PACT inhibits PKR and elF2- $\alpha$ phosphorylation, leading to an increased HIV-1 protein expression. The inhibitory role exerted by PACT over PKR seems to be related to its binding with ADAR1. The interesting conclusions of the authors are that HIV-1, inducing the expression of ADAR1, is able to change the function of PACT from an activator into an inhibitor of PKR during virus replication (Clerzius et al., 2013).

In contrast to the evidence just described, Biswas et al. (2012) proposed that ADAR1 is actually an antiviral factor against HIV-1. Upon overexpressing and silencing ADAR1 in different cells, the authors showed that ADAR 1 inhibits
HIV-1 protein accumulation by site-specific editing events in env and rev coding sequences. Unfortunately, the PKR activity was not tested in this latter setting of experiments. A very recent study also indicates ADAR 1 as a factor able to restrict HIV-1 replication (Weiden et al., 2014), even if the molecular mechanisms by which ADAR1 may play this antiviral role have not been clearly elucidated.

The discrepancies between the proviral (Clerzius et al., 2009, 2013; Doria et al., 2009; Phuphuakrat et al., 2008) and the antiviral (Biswas et al., 2012; Weiden et al., 2014) effects played by ADAR1 during HIV-1 replication are curious and may be partially due to the different cell systems and the amount of virus used.

Another member of the ADAR family, ADAR2, has been also analysed during HIV-1 infection and it has been proposed as proviral factor (Doria et al., 2011). HIV-1 target cells (Jurkat) stably silenced for ADAR2 showed a significant impairment of viral replication. Consistently, ADAR2 overexpression in producer cells (293T) enhanced p24 protein synthesis by an editing-independent mechanism, likely through an inhibitory effect over PKR. Indeed, reduced levels of phosphorylated elF2- $\alpha$ were found in cells overexpressing either the active or inactive form of ADAR2 (Doria et al., 2011). This effect was similar, even if less pronounced, to the ones observed with ADAR1 (Doria et al., 2009). Interestingly, the multistep process of the viral particle release, as observed in 293T cells, was found positively modulated by ADAR2 independently of its editing activity. Interestingly, in contrast to ADAR1, ADAR2 enzyme is not able to increase the infectious potential of HIV-1 (Doria et al., 2011). ADAR2 can target adenosines within the $5^{\prime} U T R$ of the viral RNA. Overall, ADAR2 shares some but not all the proviral functions of ADAR1.

How ADARs exert their effects during HIV-1 replication and which substrates are involved (endogenous and viral transcripts) has yet to be fully discovered. To answer this point, a deep-sequencing analysis would help to identify all the specific editing events critical for ADAR mediated HIV-1 modulation.

\section{Arenaviridae}

\section{Lymphocytic choriomeningitis virus (LCMV)}

The members of the Arenaviridae family have a negative single-stranded RNA (ss(-)RNA) genome. The viral genome of lymphocytic choriomeningitis virus (LCMV) consists of two RNA segments, the $S$ and the $L$ molecules, containing an intergenic region, which can fold into single or double stem-loop structures (Franze-Fernandez et al., 1987). The presence of an intermediate molecule consisting of dsRNA during the replication process makes the LCMV genome an excellent hypothetical substrate for ADAR enzymes. Indeed, A-to-G hypermutation pattern was detected within the LCMV RNA genome in infected murine cell lines and acutely infected mice (Zahn et al., 2007). In particular, von Laer and colleagues observed a clear A-to$G$ mutation bias in the late phases of LCMV WE strain infection (Zahn et al., 2007). They focused the analysis on the GPC glycoprotein precursor, founding that about $38 \%$ of the adenosines were converted to guanosines. The authors also observed an up-regulation of both the PKR and the ADAR1 p150 (but not of ADAR1 p110) proteins as 
a result of IFN induction due to LCMV infection (Zahn et al., 2007). About $50 \%$ of mutations in the GPC RNA segment led to the production of mutated glycoproteins, affecting their functionality. Owing to the great role played by the GPC glycoprotein precursor and its products GP-1/GP-2 in different steps of viral infection, the authors concluded that the ADAR1 p150-mediated A-to-G hypermutation in LCMV impairs viral infectivity, suggesting an antiviral role for ADAR1 p150 in IFN-induced innate defence against viruses.

In this context, the study by Oldstone and collaborators about the effect of ADAR1 in several viral infections contexts is puzzling (Ward et al., 2011), as the authors did not observed any ability of ADAR1 p150 in inhibiting LCMV.

\section{Bunyaviridae}

Rift Valley fever virus (RVFV)

Rift valley fever virus (RVFV), a segmented ss(-)RNA virus, belongs to the Bunyaviridae family. It is transmitted to animals and humans mainly through Aedes, Culex and Anopheles mosquitos (Papa et al., 2010; Seufi and Galal, 2010).

The RVFV genome consists of three RNA segments ( $\mathrm{S}, \mathrm{M}$ and $\mathrm{L}$ ), which show high nucleotide complementary at their 5'- and 3'-ends. Watson-Crick base-pairing between these two regions leads to the formation of a dsRNA secondary structure and explains why the RNA genome segments are present as circular molecules in the cytoplasm of infected cells (Pettersson and von Bonsdorff, 1975). Suspene et al. applied the 3DI-PCR technique, which allows the detection of ADAR-edited RNAs (Suspene et al., 2008) in order to selectively amplify edited products from RVFV-infected cells. The authors found extensive Ato-G hypermutations in the L segment of the RVFV RNA genome (Suspene et al., 2008). Although the authors did not identify the ADAR enzyme responsible or its biological consequences, the enhancement of A-to-I events upon IFN response suggests that the interferon-inducible ADAR1 p150 isoform may be involved.

\section{Deltavirus genus}

Hepatitis delta virus (HDV)

HDV is a small defective virus requiring HBV for its life cycle and, as a consequence, it can infect only HBsAg positive persons, in which it can lead to a more severe liver disease and eventually to death (Romeo et al., 2009). HDV can infect only hepatocytes and thus it can replicate only in the liver. This virus has a circular ss(-)RNA genome, with an envelope made up by the three HBV envelope proteins and a nucleocapsid formed by the HDV genome molecule. The HDV genome corresponds to one ORF, encoding only the two antigen HDAg proteins that exist as small (SHDAg) and large (LHDAg) isoforms (Wang et al., 1986). The first one is produced early during infection and is essential for genome replication (Kuo et al., 1989); the latter acts as an inhibitor of viral replication and is necessary to drive virion assembly (Chang et al., 1991; Chen et al., 1992). Unique among viruses, the HDV circular genome has $74 \%$ of internal basepairing and can fold into an unbranched, double-stranded, rodlike structure (Wang et al., 1986).
An event mediated by host enzymatic activity allows the generation of the functionally distinct proteins from the same HDV coding sequence. In 1986, Wang et al. identified heterogeneity at the nucleotide 1012 of the HDV genome, affecting HDAg protein length (Wang et al., 1986). Indeed, the clones with the UAG (amber) stop codon encoded the SHDAg protein, whilst the clones containing the UGG tryptophan codon encoded the LHDAg protein, which is 19 amino acids longer at the carboxyl terminus compared to the SHDAg (Wang et al., 1992). It was subsequently demonstrated that this heterogeneity was due to a specific hydrolytic deamination event at the nucleotide 1012 of the HDV genome, catalysed by the host ADAR1 p110 enzyme (Jayan and Casey, 2002b). Since this editing event changes the codon from amber to tryptophan (W), the corresponding editing site was named "amber/W site" (Polson et al., 1996). The ADAR1 p110mediated amber/W modification represents one of the best examples of site-specific editing among viral RNA substrates. Moreover, since ADAR1 p110 activity modulates the expression of these key HDV proteins and, consequently, the switch from early to late phase of infection, this enzyme plays an essential proviral role in the HDV life cycle (Wong and Lazinski, 2002; Casey, 2006).

In addition, several studies demonstrated that decreased editing levels prevent virion assembly (Jayan and Casey, 2002b, 2005), whilst increased editing levels lead to a strong RNA synthesis inhibition via LHDAg upregulation (Jayan and Casey, 2002a). Of note, as the editing event occurs on antigenome molecules that are used as template for viral genome replication, some HDV particles may contain edited copies, thus resulting in noninfectious virions, because only the LHDAg can be produced (Wong and Lazinski, 2002).

The most important message coming from all these studies is the impressive ability of HDV to redirect a host cell activity (ADAR1) towards its own advantage.

\section{Orthomyxoviridae}

\section{Influenza A virus}

The influenza A genus is a very heterogeneous virus population, whose members are responsible for seasonal and pandemic influenza in humans (Neumann et al., 2009). The influenza A genome consists of eight uncapped, segmented, linear ss(-)RNA molecules, tightly associated with viral polymerase and nucleoproteins forming viral ribonucleoproteins (vRNPs). Among the RNA segments, the segment 7 (or M mRNA) encodes for matrix proteins (such as M1 and M2). The viruses possess a host cellderived envelope membrane carrying the hemagglutinin (HA) and neuraminidase (NA) glycoproteins and the ion channel protein M2. Inside the membrane, there are the matrix protein 1 (M1) and the core vRNP complexes. Bioinformatics studies provided evidence for several regions of potentially conserved secondary structures within the positive strand of each viral segment (Gog et al., 2007).

Influenza A infection induces an extremely powerful IFN-mediated antiviral response. An interesting study from Maniatis and colleagues showed that the cellular IKKE kinase, a key factor in coordinating the IFN 
enhanceosome, is indispensable for the correct activation of some interferon-stimulated genes (ISGs) (tenOever et al., 2007). Indeed, $I K K \varepsilon^{-1}$ mice infected with the influenza $A$ WSN strain were more sensitive to infection. An array analysis revealed that a subset of ISGs was poorly induced upon infection in these mice and that the Adar1 gene was one of them. The functional consequence of Adar1 reduced expression could be the reason why the editing of the $M$ segment of influenza A genome, which is usually hyperedited in normal conditions, is strongly decreased (tenOever et al., 2007). In particular, in wild-type mice the editing level within the $M$ segment was about $30 \%$, whilst in the $I K K \varepsilon^{-}$animals the editing level decreased to about $5 \%$. Even if the biological significance of Adar1-mediated hyperediting of the $M$ segment is not yet known, it suggests that this enzyme may exert an antiviral role (tenOever et al., 2007). This hypothesis was confirmed by Oldstone and collaborators, by infecting Adar1 p150-- MEF cells with the influenza A WSN strain and observing that these cells were more sensitive to infection (Ward et al., 2011). The authors concluded that the IFN-inducible ADAR1 p150 isoform restricts the influenza $A$ virus replication and cytotoxicity, even if the mechanism of action remains to be fully elucidated (Ward et al., 2011).

Since ADAR1 p150 plays a key antiviral role in influenza $A$ infection, the finding that the virus has developed some strategies to counteract its action is not surprising. A screening by a yeast two-hybrid system has revealed that ADAR1 interacts with the influenza $A$ nonstructural protein NS1 (Suspene et al., 2011). NS1 is a critical factor antagonizing the interferon-induced host immune response, as it prevents PKR activation and affects stability and export of cellular mRNAs, inhibiting host cell gene expression (Satterly et al., 2007). Starting from these observations, Suspene et al. investigated the relationship between ADAR1 and NS1 (Suspene et al., 2011). The authors confirmed an antiviral role for ADAR1 and also suggested that the virus may contrast ADAR1 action through the NS1 protein (Suspene et al., 2011).

A certain layer of complexity has been given by a recent work from de Chassey et al. (2013), who provides insights for ADAR1 playing a supportive role in virus replication. The authors investigated the interaction between ADAR1 and the viral NS1, showing that the binding between these two factors increases ADAR1 editing activity and the viral protein expression (de Chassey et al., 2013).

Further studies are necessary to elucidate the mechanism of action of this editing enzyme over influenza A replication and to explain the apparent discrepancies emerging from the recent works.

\section{Paramyxoviridae}

The Paramyxoviridae are ss(-)RNA viruses responsible for a number of human and animal diseases. Virions are enveloped and fusion and attachment proteins emerge as spikes on the virion surface. The nucleocapsid core is composed of the genomic RNA, nucleocapsid proteins, phosphoproteins and polymerase proteins. The Paramyxoviridae includes several genera; among them, we will analyze the Morbillivirus (i.e. MV), the Pneumovirus (i.e. HRSV), the Respirovirus (i.e. HPIV3) and the Metapneumovirus (i.e. HMPV).

\section{Measles virus (MV)}

Measles virus (MV), a member of the Morbillivirus genus of the Paramyxoviridae family, is the etiologic agent of an acute infection of the respiratory system in humans. MV is an enveloped virus with a non-segmented ss(-)RNA genome (15.9 Kbp in length), which codes for at least six structural proteins and two accessory proteins ( $\mathrm{V}$ and $\mathrm{C}$ ); the latter are involved in the modulation of the host response upon MV infection. MV lacks the enzymatic machinery to reverse transcribe its own RNA genome, thus it cannot integrate DNA copies of its genomic sequences into host cellular DNA. Nevertheless, this virus can survive in neuronal/glial cells. Indeed, MV is also the aetiological agent of two rare but fatal diseases affecting the central nervous system (CNS): subacute sclerosing panencephalitis (SSPE) and measles inclusion body encephalitis (MIBE) (Billeter et al., 1994; Oldstone, 2009).

It is in this context that non-selective deaminations of adenosine residues in MV RNA were found for the first time. A few years after ADAR discovery, Cattaneo et al. (1988b) isolated viral RNAs from the brain of one MIBE patient and two SSPE patients that contained almost $2 \%$ of the nucleotides mutated in comparison with the control sequence of MV. In particular, the viral matrix (M) mRNA of the MIBE case showed clustered A-to-I/G mutations. Similar transitions were largely observed in cDNAs derived from other cases of persistent MV infection in the $M$ gene as well as in other MV genes (i.e. $\mathrm{H}$ and $\mathrm{F}$ genes) (Billeter et al., 1994). Notably, such biased hypermutations have not been found in MV strains causing acute infections. The extensive sequence changes in the $M$ transcript are presumed to prevent synthesis of a functional factor, the matrix protein, that is required for virion assembly and release and it may be involved in helping the virus to escape immune system recognition, allowing persistent infections in the brain (Cattaneo et al., 1988a; Patterson et al., 2001).

Later, it was shown that the IFN-inducible ADAR1 p150 can extensively edit MV (about $83 \%$ of edited adenosine) in a cell culture infection system (Suspene et al., 2008, 2011). These evidences suggested a role for ADAR1 during MV infection, although the effective consequences on the viral life cycle and the mechanism by which these hypermutations arise in the viral genome remain largely unknown. Later, human HeLa cells stably silenced for ADAR1 were infected with MV (Toth et al., 2009). The growth of MV wild-type (WT) as well as of two mutant viruses lacking expression of the accessory proteins $\mathrm{V}\left(\mathrm{V}^{\mathrm{ko}}\right)$ and $C\left(C^{k o}\right)$ were significantly decreased in ADAR1deficient (ADAR1 ${ }^{\mathrm{ko}}$ ) cells compared to the controls. The authors also observed that MV-induced apoptosis was further enhanced in the ADAR $1^{\mathrm{ko}}$ cells, suggesting that ADAR1 suppresses virus-induced cytotoxicity. This proviral and anti-apoptotic role of ADAR1 during MV infection probably correlates with a negative modulation of the PKR pathway, as ADAR1ko HeLa cells showed an increased phosphorylation/activation of PKR, elF2- $\alpha$ and IFN regulatory factor 3 (IRF3) (Toth et al., 2009). 
Biological evidence connecting ADAR1 and MV came also from Ward et al. (2011). MEF cells stably expressing the receptor for MV were specifically silenced for the Adar1 p150 gene. This cell line showed a higher cytotoxic effect upon MV infection with an enhanced viral growth compared with the controls. The authors showed that deletion of Adar1 p150 increases cell susceptibility to MV as well as to other members of Paramyxoviridae and Orthomyxoviridae family.

The discrepancy between the above cited studies indicating the proviral (Toth et al., 2009) and the antiviral (Ward et al., 2011) effect of ADAR1, observed in the MV replication context, may be due to differences in the cell type, virus strains and levels of ADAR1 depletion used in the two studies.

Recent works further explored the role of ADAR1 during MV infection. A first study showed that ADAR1 is able to suppress the MV-induced production of IFN- $\beta$ RNA, by suppressing IRF3 and promoting the activating transcription factor 2 (ATF2) (Li et al., 2012). Furthermore, other studies demonstrated that only the deaminase catalytic active ADAR1 p150 isoform, and not the p110, is able to suppress the cellular stress granule (SG) formation, a host response to virus infection (Okonski and Samuel, 2013; John and Samuel, 2014).

Taken together these recent studies demonstrate that the active ADAR1 p150 downregulates host innate immune responses to MV infection by multiple mechanisms, such as suppressing the activation of PKR, the induction of IFN$\beta$ RNA and the formation of stress granules.

\section{Human respiratory syncytial virus (HRSV)}

Human respiratory syncytial virus (HRSV) is a member of the Pneumovirus genus of the Paramyxoviridae family. HRSV is the leading cause of severe lower respiratory tract infections in very young children and infants (Collins, 1996). HRSV has a non-segmented ss(-)RNA genome with 10 genes encoding 11 proteins, including the G protein, a surface protein heavily glycosylated and essential for virus attachment to the cell surface receptor. Multiple A-to-G (U-to-C in the positive sense) nucleotide substitutions have been found exclusively in the viral attachment glycoprotein G (Rueda et al., 1994; Martinez et al., 1997; Walsh et al., 1998), which helped the virus to escape immunological response (Martinez et al., 1997; Walsh et al., 1998). ADAR enzymes were supposed to be involved in these viral hypermutations (Martinez et al., 1997; Martinez and Melero, 2002). Indeed, short intramolecular dsRNA segments (100-200 bp) can be transiently formed during HRSV replication and/or transcription and could be a good substrate for RNA editing. Furthermore, the central region of the $G$ protein fulfils all the requirements for ADAR binding/editing, having an AU-rich region and a high tendency for intramolecular base pairing (Martinez and Melero, 2002).

Of note, ssRNAs containing inosines (Ino-RNAs), transfected in cell infected by HRSV, strongly induce inflammatory cytokines (i.e. IFN- $\beta$ and IL-6) and reduces HRSV replication. This antiviral effect seems to be mediated by an increased PKR activation (Liao et al., 2011).
Human parainflenza virus 3 (HPIV3)

Human parainflenza virus 3 (HPIV3) belongs to the Respirovirus genus of the Paramyxoviridae family. RNAs isolated from two lines of persistently infected rhesus monkey kidney LLC-MK2 cells showed biased A-to-I(G) and U-to-C transitions within the $3^{\prime}$-end, consistent with editing mediated by an ADAR enzyme (Murphy et al., 1991). The biological significance of this hyperediting has still to be investigated.

\section{Human metapneumovirus (HMPV)}

The HMPV genome is a ss(-)RNA molecule and contains at least 8 genes encoding for 9 viral proteins. It has been recently demonstrated by deep-sequencing analysis and Northern blot experiments that HMPV accumulates defective interfering RNAs (DI-RNAs), which are mutated subviral RNAs playing a role in the evolution of viral diseases and are spontaneously produced by error-prone viral machineries.

Extensive A-to-G nucleotide substitutions were detected in the viral DI-RNAs, consistent with modifications catalysed by ADAR enzymes (van den Hoogen et al., 2014). Since ADAR1 p150 is an IFN-inducible protein, the authors speculated that the mutations found in HPMV DIRNAs were mediated by this isoform (van den Hoogen et al., 2014).

\section{Rhabdoviridae}

Vesicular stomatitis virus (VSV)

Rhabdoviruses infect a wide host range, which comprise plants, insects and vertebrates, including mammals and humans. The VSV genome consists of a linear, ss(-)RNA molecule of $11 \mathrm{Kbp}$, which comprises five separate ORFs, interspersed by 'intergenic regions' (Finke et al., 2000). Interestingly, VSV has been shown to be susceptible to PKR: in fact, $P K R^{-1}$ mice dye following VSV infection and fibroblasts isolated from $P K R^{-/}$mice are more permissive to VSV infection than the wild-type counterpart (Balachandran and Barber, 2000; Stojdl et al., 2000).

A great deal of effort has been spent in the last years to investigate the relationship among VSV, host immune response and ADAR1. Yang and co-workers showed that stable overexpression of Adar1 p150 in NIH3T3 and MEF cells significantly sensitized host cells to VSV infection (Nie et al., 2007). Accordingly, a transient silencing of endogenous ADAR1 made 293T cells more resistant to infection. The authors further demonstrated that this proviral role of ADAR1 was PKR-dependent and editingindependent (Nie et al., 2007).

A later study from Li et al. showed that VSV growth was unaffected by both ADAR1 p150 and ADAR2 editing enzymes ( $\mathrm{Li}$ et al., 2010). The discrepancy between overexpression experiments performed by $\mathrm{Nie}$ et al. (murine cell lines) and $\mathrm{Li}$ et al. (human cell line) suggests that different host cell types may have different responses to VSV infection.

Overall, these findings suggest that RNA editing may be excluded as a mechanism against VSV infection. However, the analysis of defective interfering (DI) VSV particles from infected hamster kidney fibroblast BHK cells 
showed significant A-to-G modifications in the viral genome (O'Hara et al., 1984).

Notably, ADAR-mediated hyperediting was also detected in the PP3 viral transcript of another Rhabdovirus, the Drosophila sigma virus (Carpenter et al., 2009), with a possible antiviral role at least in insects.

\section{Future perspectives}

Adenosine deaminases that act on dsRNA (ADARs) are a family of enzymes whose activity is substrate-, cell-, tissueand time of development-dependent. Different lines of evidence suggest the existence of a complex and essential interplay between ADAR, viruses and immunological response. The comprehension of the mechanisms controlling the activity of these editing enzymes is essential to get a clear picture of their action upon viral infection in vivo.

Considerable advances have been made toward understanding the biochemistry and the regulation of the ADAR proteins; however, the physiological consequences of their expression/activity during viral infection are still not completely elucidated.

We learned that the effects of ADARs and A-to-I editing during viral infection can be either antiviral or proviral, depending on the virus-host combination. Moreover, we found that the interplay between ADARs and viruses is highly dynamic and can change during the progression of the infection. Indeed, ADAR expression, virus infection and IFN-response lead to profound changes in the profile of both viral and cellular genes/miRNAs that, in turn, can alter the virus-host interaction.

Future investigations on ADARs and viral infections will shed lights on this fascinating interaction between pathogens and host-immune response and will help to better understand the action and regulation of these multitasking editing enzymes.

\section{Acknowledgments}

This work was supported by an IG grant (n. 13202) to A.G. from AIRC (Associazione Italiana Ricerca sul Cancro) and by the special project 5 X 1000 AIRC to F.L.

\section{References.}

Alisi, A., Tomaselli, S., Balsano, C., and Gallo, A. (2011). Hepatitis C virus therapeutics: editing enzymes promising therapeutic targets? Hepatology 54, 742; author reply 742-743.

Arias, C., Weisburd, B., Stern-Ginossar, N., Mercier, A., Madrid, A.S., Bellare, P., Holdorf, M., Weissman, J.S., and Ganem, D. (2014). KSHV 2.0: A Comprehensive Annotation of the Kaposi's Sarcoma-Associated Herpesvirus Genome Using Next-Generation Sequencing Reveals Novel Genomic and Functional Features. PLoS Pathog. 10, e1003847. .

Balachandran, S., and Barber, G.N. (2000). Vesicular stomatitis virus (VSV) therapy of tumors. IUBMB life 50, 135-138.

Barre-Sinoussi, F., Chermann, J.C., Rey, F., Nugeyre, M.T., Chamaret, S., Gruest, J., Dauguet, C., Axler-Blin, C., Vezinet-Brun, F., Rouzioux, C., et al. (1983). Isolation of a T-lymphotropic retrovirus from a patient at risk for acquired immune deficiency syndrome (AIDS). Science 220, 868-871.

Bass, B.L., and Weintraub, H. (1988). An unwinding activity that covalently modifies its double-stranded RNA substrate. Cell 55, 1089-1098.

Becher, P., and Thiel, H.J. (2002). Genus Pestivirus (Flaviviridae). In The Springer index of viruses (Tidona, C.A., and Darai, G., eds.), pp 327-331, Springer-Verlag, Heidelberg.

Billeter, M.A., Cattaneo, R., Spielhofer, P., Kaelin, K., Huber, M., Schmid, A., Baczko, K., and ter Meulen, V. (1994). Generation and properties of measles virus mutations typically associated with subacute sclerosing panencephalitis. Ann. N.Y. Acad. Sci. 724, 367-377.

Biswas, N., Wang, T., Ding, M., Tumne, A., Chen, Y., Wang, Q., and Gupta, P. (2012). ADAR1 is a novel multi targeted anti-HIV-1 cellular protein. Virology 422, 265277.

Carpenter, J.A., Keegan, L.P., Wilfert, L., O'Connell, M.A., and Jiggins, F.M. (2009). Evidence for ADAR-induced hypermutation of the Drosophila sigma virus (Rhabdoviridae). BMC genetics 10, 75.

Casey, J.L. (2006). RNA editing in hepatitis delta virus. Curr. Top. Microbiol. Immunol. 307, 67-89.

Cathomas, G. (2003). Kaposi's sarcoma-associated herpesvirus (KSHV)/human herpesvirus 8 (HHV-8) as a tumour virus. Herpes 10, 72-77.

Cattaneo, R., Schmid, A., Billeter, M.A., Sheppard, R.D., and Udem, S.A. (1988a). Multiple viral mutations rather than host factors cause defective measles virus gene expression in a subacute sclerosing panencephalitis cell line. J. Virol. 62, 1388-1397.

Cattaneo, R., Schmid, A., Eschle, D., Baczko, K., ter Meulen, V., and Billeter, M.A. (1988b). Biased hypermutation and other genetic changes in defective measles viruses in human brain infections. Cell 55, 255265.

Chang, F.L., Chen, P.J., Tu, S.J., Wang, C.J., and Chen, D.S. (1991). The large form of hepatitis delta antigen is crucial for assembly of hepatitis delta virus. Proc. Natl. Acad. Sci. U.S.A. 88, 8490-8494.

Chen, P.J., Chang, F.L., Wang, C.J., Lin, C.J., Sung, S.Y., and Chen, D.S. (1992). Functional study of hepatitis delta virus large antigen in packaging and replication inhibition: role of the amino-terminal leucine zipper. J. Virol. 66, 2853-2859.

Choo, Q.L., Kuo, G., Weiner, A.J., Overby, L.R., Bradley, D.W., and Houghton, M. (1989). Isolation of a cDNA clone derived from a blood-borne non-A, non-B viral hepatitis genome. Science 244, 359-362.

Choo, Q.L., Richman, K.H., Han, J.H., Berger, K., Lee, C., Dong, C., Gallegos, C., Coit, D., Medina-Selby, R., Barr, P.J., et al. (1991). Genetic organization and diversity of the hepatitis C virus. Proc. Natl. Acad. Sci. U.S.A. 88, 2451-2455.

Clement, S., Pascarella, S., and Negro, F. (2009). Hepatitis $C$ virus infection: molecular pathways to steatosis, insulin resistance and oxidative stress. Viruses 1, 126-143.

Clerzius, G., Gelinas, J.F., Daher, A., Bonnet, M., Meurs, E.F., and Gatignol, A. (2009). ADAR1 interacts with PKR during human immunodeficiency virus infection of 
lymphocytes and contributes to viral replication. J. Virol. 83, 10119-10128.

Clerzius, G., Gelinas, J.F., and Gatignol, A. (2011). Multiple levels of PKR inhibition during HIV-1 replication. Rev. Med. Virol. 21, 42-53.

Clerzius, G., Shaw, E., Daher, A., Burugu, S., Gélinas, J.F., Ear, T., Sinck, L., Routy, J.P., Mouland, A.J., Patel, R.C., et al. (2013). The PKR activator, PACT, becomes a PKR inhibitor during HIV-1 replication. Retrovirology 10, 96.

Collins, P.L., Mclntosh, K., and Chanock, R.M. (1996). Respiratory Syncytial Virus. In Fields Virology (Fields, B.N., Knipe, D.M., and Howley. P.M., eds), 3rd edn, pp 1313-1351, Lippincott-Raven, Philadelphia.

Cullen, B.R. (2009). Viral and cellular messenger RNA targets of viral microRNAs. Nature 457, 421-425.

Damania, B. (2004). Oncogenic gamma-herpesviruses: comparison of viral proteins involved in tumorigenesis. Nat. Rev. 2, 656-668.

de Chassey, B., Aublin-Gex, A., Ruggieri, A., MeynielSchicklin, L., Pradezynski, F., Davoust, N., Chantier, T., Tafforeau, L., Mangeot, P.E., Ciancia, C., et al. (2013). The interactomes of influenza virus NS1 and NS2 proteins identify new host factors and provide insights for ADAR1 playing a supportive role in virus replication. PLoS Pathog. 9, e1003440. .

Doria, M., Neri, F., Gallo, A., Farace, M.G., and Michienzi, A. (2009). Editing of HIV-1 RNA by the double-stranded RNA deaminase ADAR1 stimulates viral infection. Nucleic Acids Res. 37, 5848-5858.

Doria, M., Tomaselli, S., Neri, F., Ciafre, S.A., Farace, M.G., Michienzi, A., and Gallo, A. (2011). The ADAR2 editing enzyme is a novel Hiv-1 proviral factor. J. Gen. Virol. 92, 1228-1232.

Felder, M.P., Laugier, D., Yatsula, B., Dezelee, P., Calothy, G., and Marx, M. (1994). Functional and biological properties of an avian variant long terminal repeat containing multiple $A$ to $G$ conversions in the U3 sequence. J. Virol. 68, 4759-4767.

Finke, S., Cox, J.H., and Conzelmann, K.K. (2000). Differential transcription attenuation of rabies virus genes by intergenic regions: generation of recombinant viruses overexpressing the polymerase gene. J. Virol. 74, 72617269.

Franze-Fernandez, M.T., Zetina, C., lapalucci, S., Lucero, M.A., Bouissou, C., Lopez, R., Rey, O., Daheli, M., Cohen, G.N., and Zakin, M.M. (1987). Molecular structure and early events in the replication of Tacaribe arenavirus S RNA. Virus Res. 7, 309-324.

Gale, M.Jr., and Katze, M.G. (1998). Molecular mechanisms of interferon resistance mediated by viraldirected inhibition of $\mathrm{PKR}$, the interferon-induced protein kinase. Pharmacol. Ther. 78, 29-46. .

Gallo, A., and Locatelli, F. (2011). ADARs: allies or enemies? The importance of A-to-I RNA editing in human disease: from cancer to HIV-1. Biol. Rev. Camb. Philos. Soc. 87, 95-110.

Gallo, R.C., Sarin, P.S., Gelmann, E.P., Robert-Guroff, M., Richardson, E., Kalyanaraman, V.S., Mann, D., Sidhu, G.D., Stahl, R.E., Zolla-Pazner, S., et al. (1983). Isolation of human T-cell leukemia virus in acquired immune deficiency syndrome (AIDS). Science 220, 865-867.
Gandy, S.Z., Linnstaedt, S.D., Muralidhar, S., Cashman, K.A., Rosenthal, L.J., and Casey, J.L. (2007). RNA editing of the human herpesvirus 8 kaposin transcript eliminates its transforming activity and is induced during Iytic replication. J. Virol. 81, 13544-13551.

Garcia, M.A., Gil, J., Ventoso, I., Guerra, S., Domingo, E., Rivas, C., and Esteban, M. (2006). Impact of protein kinase PKR in cell biology: from antiviral to antiproliferative action. Microbiol. Mol. Biol. Rev. 70, 1032-1060.

George, C.X., and Samuel, C.E. (2011). Host response to polyomavirus infection is modulated by RNA adenosine deaminase ADAR1 but not by ADAR2. J. Virol. 85, 83388347.

George, C.X., Li, Z., Okonski, K.M., Toth, A.M., Wang, Y., and Samuel, C.E. (2009). Tipping the balance: antagonism of PKR kinase and ADAR1 deaminase functions by virus gene products. J. Interferon. Cytokine Res. 29, 477-487.

Gog, J.R., Afonso Edos, S., Dalton, R.M., Leclercq, I., Tiley, L., Elton, D., von Kirchbach, J.C., Naffakh, N., Escriou, N., and Digard, P. (2007). Codon conservation in the influenza A virus genome defines RNA packaging signals. Nucleic Acids Res. 35, 1897-1907.

Gu, R., Zhang, Z., and Carmichael, G.G. (2006). How a small DNA virus uses dsRNA but not RNAi to regulate its life cycle. Cold Spring Harb. Symp. Quant. Biol. 71, 293299.

Gu, R., Zhang, Z., DeCerbo, J.N., and Carmichael, G.G. (2009). Gene regulation by sense-antisense overlap of polyadenylation signals. RNA 15, 1154-1163. .

Hajjar, A.M., and Linial, M.L. (1995). Modification of retroviral RNA by double-stranded RNA adenosine deaminase. J. Virol. 69, 5878-5882.

Hyde-DeRuyscher, R., and Carmichael, G.G. (1988). Polyomavirus early-late switch is not regulated at the level of transcription initiation and is associated with changes in RNA processing. Proc. Natl. Acad. Sci. U.S.A. 85, 8993-8997.

Iglesias N.G., and Gamarnik, A.V. (2011). Dynamic RNA structures in the dengue virus genome. RNA Biol. 8, 249-257.

lizasa, H., Wulff, B.E., Alla, N.R., Maragkakis, M., Megraw, M., Hatzigeorgiou, A., Iwakiri, D., Takada, K., Wiedmer, A., Showe, L., et al. (2010). Editing of Epstein-Barr virusencoded BART6 microRNAs controls their dicer targeting and consequently affects viral latency. J. Biol. Chem. 285, 33358-33370.

Ito, T., Tahara, S.M., and Lai, M.M. (1998). The 3'untraslated region of hepatitis $C$ virus RNA enhances translation from an internal ribosomal entry site. J. Virol. 72, 783-786.

Jayan, G.C., and Casey, J.L. (2002a). Increased RNA editing and inhibition of hepatitis delta virus

replication by high-level expression of ADAR1 and ADAR2. J. Virol. 76, 3819-3827.

Jayan, G.C., and Casey, J.L. (2002b). Inhibition of hepatitis delta virus RNA editing by short inhibitory RNA-mediated knockdown of ADAR1 but not ADAR2 expression. J. Virol. 76, 12399-12404.

Jayan, G.C., and Casey, J.L. (2005). Effects of conserved RNA secondary structures on hepatitis delta virus 
genotype I RNA editing, replication, and virus production. J. Virol. 79, 11187-11193.

John, L., and Samuel, C.E. (2014). Induction of stress granules by interferon and down-regulation by the cellular RNA adenosine deaminase ADAR1. Virology 454-455, 299-310.

Ko, N.L., Birlouez, E., Wain-Hobson, S., Mahieux, R., and Vartanian, J.P. (2012). Hyperediting of human T-cell leukemia virus type 2 and simian T-cell leukemia virus type 3 by the dsRNA adenosine deaminase ADAR-1. J. Gen. Virol. 93, 2646-2651.

Kumar, M., and Carmichael, G.G. (1997). Nuclear antisense RNA induces extensive adenosine modifications and nuclear retention of target transcripts. Proc. Natl. Acad. Sci. U.S.A. 94, 3542-3547.

Kuo, M.Y., Chao, M., and Taylor, J. (1989). Initiation of replication of the human hepatitis delta virus genome from cloned DNA: role of delta antigen. J. Virol. 63, 1945-1950.

Lei, T., Yuen, K., Tsao, S.W., Chen, H., Kok, K., and Jin, D. (2013). Perturbation of biogenesis and targeting of Epstein-Barr virus-encoded miR-BART3 microRNA by adenosine-to-inosine editing. J. Gen. Virol. 94, 27392744. .

Lemaire, P.A., Anderson, E., Lary, J., and Cole, J.L. (2008). Mechanism of PKR Activation by dsRNA. J. Mol. Biol. $381,351-360$.

Levrero, M. (2006). Viral hepatitis and liver cancer: the case of hepatitis C. Oncogene 25, 3834-3847.

Li, Y., Masaki, T., Shimakami, T., and Lemon, S.M. (2014). hnRNP L and NF90 interact with hepatitis C virus 5'terminal untraslated RNA and promote efficient replication. J. Virol. 88, 7199-7209.

Li, Z., Okonski, K.M., and Samuel, C.E. (2012). Adenosine deaminase acting on RNA 1 (ADAR1) supresses the induction of interferon by measles virus. J. Gen. Virol. 86, 3787-3794.

Li, Z., Wolff, K.C., and Samuel, C.E. (2010). RNA adenosine deaminase ADAR1 deficiency leads to increased activation of protein kinase PKR and reduced vesicular stomatitis virus growth following interferon treatment. Virology 396, 316-322.

Liao, J., Thakur, S.A., Zalinger, Z.B., Gerrish, K.E., and Imani, F. (2011). Inosine-containing RNA is a novel innate immune Recognition element and reduces RSV infection. PLoS One 6, e26463.

Lindenbach, B.D., and Rice, C.M. (2001). Flaviviridae: the viruses and their replication. In Fields Virology (Fields, B.N., Knipe, D.M., and Howley. P.M., eds), 4th edn, pp 991-1042, Lippincott-Raven, Philadelphia.

Liu, Z., and Carmichael, G.G. (1993). Polyoma virus earlylate switch: regulation of late RNA accumulation by DNA replication. Proc. Natl. Acad. Sci. U.S.A. 90, 8494-8498.

Liu, Z., and Carmichael, G.G. (1994). Nuclear antisense RNA. An efficient new method to inhibit gene expression. Mol. Biotechnol. 2, 107-118.

Martinez, I., and Melero, J.A. (2002). A model for the generation of multiple $A$ to $G$ transitions in the human respiratory syncytial virus genome: predicted RNA secondary structures as substrates for adenosine deaminases that act on RNA. J. Gen. Virol. 83, 14451455.
Martinez, I., Dopazo, J., and Melero, J.A. (1997). Antigenic structure of the human respiratory syncytial virus $G$ glycoprotein and relevance of hypermutation events for the generation of antigenic variants. Gen, J. . Virol. 78 (Pt 10), 2419-2429.

Meurs, E., Chong, K., Galabru, J., Thomas, N.S., Kerr, I.M., Williams, B.R., and Hovanessian, A.G. (1990). Molecular cloning and characterization of the human doublestranded RNA-activated protein kinase induced by interferon. Cell 62, 379-390.

Mohamed, Y.M., Bangphoomi, N., Yamane, D., Suda, Y., Kato, K., Horimoto, T., and Akashi, H. (2014). Physical interaction between bovine viral diarrhea virus nonstructural protein $4 \mathrm{~A}$ and adenosine deaminase acting on RNA (ADAR). Arch. Virol. 159, 1735-1741.

Muralidhar, S., Pumfery, A.M., Hassani, M., Sadaie, M.R., Kishishita, M., Brady, J.N., Doniger, J., Medveczky, P., and Rosenthal, L.J. (1998). Identification of kaposin (open reading frame $\mathrm{K} 12$ ) as a human herpesvirus 8 (Kaposi's sarcoma-associated herpesvirus) transforming gene. J. Virol. 72, 4980-4988.

Muralidhar, S., Veytsmann, G., Chandran, B., Ablashi, D., Doniger, J., and Rosenthal, L.J. (2000). Characterization of the human herpesvirus 8 (Kaposi's sarcomaassociated herpesvirus) oncogene, kaposin (ORF K12). J. Clin. Virol. 16, 203-213.

Murphy, D.G., Dimock, K., and Kang, C.Y. (1991). Numerous transitions in human parainfluenza virus 3 RNA recovered from persistently infected cells. Virology 181, 760-763.

Neumann, G., Chen, H., Gao, G.F., Shu, Y., and Kawaoka, Y. (2009). H5N1 influenza viruses: outbreaks and biological properties. Cell Res. 20, 51-61.

Nie, Y., Ding, L., Kao, P.N., Braun, R., and Yang, J.H. (2005). ADAR1 interacts with NF90 through doublestranded RNA and regulates NF90-mediated gene expression independently of RNA editing. Mol. Cell. Biol. 25, 6956-6963.

Nie, Y., Hammond, G.L., and Yang, J.H. (2007). Double stranded RNA deaminase ADAR1 increases host susceptibility to virus infection. J. Virol. 81, 917-923.

O'Hara, P.J., Nichol, S.T., Horodyski, F.M., and Holland, J.J. (1984). Vesicular stomatitis virus defective interfering particles can contain extensive genomic sequence rearrangements and base substitutions. Cell 36, 915924.

Ohsaki, E., and Ueda, K. (2012). Kaposi's sarcomaassociated Herpesvirus genome replication,

partitioning, and maintenance in latency. Front. Microbiol. 3,7 .

Okonski, K.M., and Samuel, C.E. (2013). Stress granule formation induced by measles virus is protein kinase PKR dependent and impaired by RNA adenosine deaminase ADAR1. J. Gen. Virol. 87, 756-766.

Oldstone, M.B. (2009). Modeling subacute sclerosing panencephalitis in a transgenic mouse system: uncoding pathogenesis of disease and illuminating components of immune control. Curr. Top. Microbiol. Immunol. 330, 3154.

Papa, A., Dalla, V., Petala, A., Maltezou, H.C., and Maltezos, E. (2010). Fatal Mediterranean spotted fever in Greece. Clin. Microbiol. Infect. 16, 589-592. 
Patel, R.C., and Sen, G.C. (1998). PACT, a protein activator of the interferon-induced protein kinase, PKR. EMBO J. 17, 4379-4390.

Patel, C.V., Handy, I., Goldsmith, T. and Patel, R.C. (2000). PACT, a stress-modulated cellular activator of interferoninduced double-stranded RNA-activated protein kinase, PKR. J. Biol. Chem. 275, 37993-37998.

Patterson, J.B., and Samuel, C.E. (1995). Expression and regulation by interferon of a double-strandedRNAspecific adenosine deaminase from human cells: evidence for two forms of the deaminase. Mol. Cell. Biol. 15, 5376-5388.

Patterson, J.B., Cornu, T.I., Redwine, J., Dales, S., Lewicki, H., Holz, A., Thomas, D., Billeter, M.A., and Oldstone, M.B. (2001). Evidence that the hypermutated M protein of a subacute sclerosing panencephalitis measles virus actively contributes to the chronic progressive CNS disease. Virology 291, 215-225.

Pettersson, R.F., and von Bonsdorff, C.H. (1975). Ribonucleoproteins of Uukuniemi virus are circular. J. Virol. 15, 386-392.

Pfaller, C.K., Li, Z., George, C.X., and Samuel, C.E. (2011). Protein kinase PKR and RNA adenosine deaminase ADAR1: new roles for old players as modulators of the interferon response. Curr. Opin. Immunol. 23, 573-582.

Pfeffer, S., Sewer, A., Lagos-Quintana, M., Sheridan, R., Sander, C., Grasser, F.A., van Dyk, L.F., Ho, C.K., Shuman, S., Chien, M., et al. (2005). Identification of microRNAs of the herpesvirus family. Nat. Methods 2, 269-276.

Phuphuakrat, A., Kraiwong, R., Boonarkart, C., Lauhakirti, D., Lee, T.H., and Auewarakul, P. (2008). Doublestranded RNA adenosine deaminases enhance expression of human immunodeficiency virus type 1 proteins. J. Virol. 82, 10864-10872.

Polson, A.G., Bass, B.L., and Casey, J.L. (1996). RNA editing of hepatitis delta virus antigenome by dsRNAadenosine deaminase. Nature 380, 454-456.

Raza, S.A., Clifford, G.M., and Franceschi, S. (2007). Worldwide variation in the relative importance of hepatitis $B$ and hepatitis $C$ viruses in hepatocellular carcinoma: a systematic review. Br. J. Cancer 96, 1127-1134.

Rice, C. M. (1996). Flaviviridae: the viruses and their replication. In Fields Virology (Fields, B.N., Knipe, D.M., and Howley. P.M., eds), 3rd edn, pp 931-960, LippincottRaven, Philadelphia.

Romeo, R., Del Ninno, E., Rumi, M., Russo, A., Sangiovanni, A., de Franchis, R., Ronchi, G., and Colombo, M. (2009). A 28-year study of the course of hepatitis Delta infection: a risk factor for cirrhosis and hepatocellular carcinoma. Gastroenterology 136, 16291638.

Rueda, P., Garcia-Barreno, B., and Melero, J.A. (1994). Loss of conserved cysteine residues in the attachment (G) glycoprotein of two human respiratory syncytial virus escape mutants that contain multiple A-G substitutions (hypermutations). Virology 198, 653-662.

Sadler, A.J., and Williams, B.R. (2007). Structure and function of the protein kinase R. Curr. Top. Microbiol. Immunol. 316, 253-292.

Sadler, R., Wu, L., Forghani, B., Renne, R., Zhong, W., Herndier, B., and Ganem, D. (1999). A complex translational program generates multiple novel proteins from the latently expressed kaposin (K12) locus of Kaposi's sarcoma-associated herpesvirus. J. Virol. 73, 5722-5730.

Samuel, C.E. (2011). Adenosine deaminases acting on RNA (ADARs) are both antiviral and proviral. Virology 411, 180-193.

Satterly, N., Tsai, P.L., van Deursen, J., Nussenzveig, D.R., Wang, Y., Faria, P.A., Levay, A., Levy, D.E., and Fontoura, B.M. (2007). Influenza virus targets the mRNA export machinery and the nuclear pore complex. Proc. Natl. Acad. Sci. U.S.A. 104, 1853-1858.

Seufi, A.M., and Galal, F.H. (2010). Role of Culex and Anopheles mosquito species as potential vectors of rift valley fever virus in Sudan outbreak, 2007. BMC Infect. Dis. 10, 65.

Sharmeen, L., Bass, B., Sonenberg, N., Weintraub, H., and Groudine, M. (1991). Tat-dependent adenosine-toinosine modification of wild-type transactivation response RNA. Proc. Natl. Acad. Sci. U.S.A. 88, 8096-8100.

Simmonds, P. (2004). Genetic diversity and evolution of hepatitis C virus - 15 years on. J. Gen. Virol. 85, 31733188.

Singh, M., Patel, R.C. (2012). Increased interaction between PACT molecules in response to stress signals is required for PKR activation. J. Cell. Biochem. 113, 27542764.

Skalsky, R.L., and Cullen, B.R. (2010). Viruses, microRNAs, and host interactions. Annu. Rev. Microbiol. 64, 123-141.

Slattery, J.P., Franchini, G. and Gessain, A. (1999). Genomic evolution, patterns of global dissemination, and interspecies transmission of human and simian T-cell leukemia/lymphotropic viruses. Genome Res. 9, 525540.

Stojdl, D.F., Abraham, N., Knowles, S., Marius, R., Brasey, A., Lichty, B.D., Brown, E.G., Sonenberg, N., and Bell, J.C. (2000). The murine double-stranded RNAdependent protein kinase PKR is required for resistance to vesicular stomatitis virus. J. Virol. 74, 9580-9585.

Suspene, R., Renard, M., Henry, M., Guetard, D., Puyraimond-Zemmour, D., Billecocq, A., Bouloy, M., Tangy, F., Vartanian, J.P., and Wain-Hobson, S. (2008). Inversing the natural hydrogen bonding rule to selectively amplify GC-rich ADAR-edited RNAs. Nucleic Acids Res. 36, e72.

Suspene, R., Petit, V., Puyraimond-Zemmour, D., Aynaud, M.M., Henry, M., Guetard, D., Rusniok, C., Wain-Hobson, S., and Vartanian, J.P. (2011). Double-stranded RNA adenosine deaminase ADAR-1-induced hypermutated genomes among inactivated seasonal influenza and live attenuated measles virus vaccines. J. Virol. 85, 24582462.

Talbot, S.J., and Crawford, D.H. (2004). Viruses and tumours-an update. Eur. J. Cancer 40, 1998-2005.

Taylor, D.R., Puig, M., Darnell, M.E., Mihalik, K., and Feinstone, S.M. (2005). New antiviral pathway that mediates hepatitis $C$ virus replicon interferon sensitivity through ADAR1. J. Virol. 79, 6291-6298.

tenOever, B.R., Ng, S.L., Chua, M.A., McWhirter, S.M., Garcia-Sastre, A., and Maniatis, T. (2007). Multiple functions of the IKK-related kinase IKKepsilon in 
interferon-mediated antiviral immunity. Science 315, 1274-1278.

Tomaselli, S., Locatelli, F. and Gallo, A. (2014). The RNA editing enzymes ADARs: mechanism of action and human disease. Cell Tissue Res. 356:527-532.

Toth, A.M., Li, Z., Cattaneo, R., and Samuel, C.E. (2009). RNA-specific adenosine deaminase ADAR1 suppresses measles virus-induced apoptosis and activation of protein kinase PKR. J. Biol. Chem. 284, 29350-29356.

Tuplin, A., Wood, J., Evans, D.J., Patel, A.H., and Simmonds, P. (2002). Thermodynamic and phylogenetic prediction of RNA secondary structures in the coding region of hepatitis $C$ virus. RNA 8, 824-841.

van den Hoogen, B.G., van Boheemen, S., de Rijck, J., van Nieuwkoop, S., Smith, D.J., Laksono, B., Gultyaev, A., Osterhaus, A.D., Fouchier, R.A. (2014). Excessive production and extreme editing of human metapneumovirus defective interfering RNA is associated with type I IFN induction. J Gen. Virol. 95:1625-1633.

Wagner, R.W., Smith, J.E., Cooperman, B.S., and Nishikura, K. (1989). A double-stranded RNA unwinding activity introduces structural alterations by means of adenosine to inosine conversions in mammalian cells and Xenopus eggs. Proc. Natl. Acad. Sci. U.S.A. 86, 2647-2651.

Walsh, E.E., Falsey, A.R., and Sullender, W.M. (1998). Monoclonal antibody neutralization escape mutants of respiratory syncytial virus with unique alterations in the attachment (G) protein. Gen, J. Virol. 79(Pt 3), 479-487.

Wang, J.G., Cullen, J., and Lemon, S.M. (1992). Immunoblot analysis demonstrates that the large and small forms of hepatitis delta virus antigen have different
C-terminal amino acid sequences. J. Virol. 73(Pt 1), 183188.

Wang, K.S., Choo, Q.L., Weiner, A.J., Ou, J.H., Najarian, R.C., Thayer, R.M., Mullenbach, G.T., Denniston, K.J., Gerin, J.L., and Houghton, M. (1986). Structure, sequence and expression of the hepatitis delta (delta) viral genome. Nature 323, 508-514.

Ward, S.V., George, C.X., Welch, M.J., Liou, L.Y., Hahm, B., Lewicki, H., de la Torre, J.C., Samuel, C.E., and Oldstone, M.B. (2011). RNA editing enzyme adenosine deaminase is a restriction factor for controlling measles virus replication that also is required for embryogenesis. Proc. Natl. Acad. Sci. U.S.A. 108, 331-336.

Weiden, M.D., Hoshino, S., Levy, D.N., Li, Y., Kumar, R., Burke, S.A., Dawson, R., Hioe, C.E., Borkowsky, W., Rom, W.N., et al. (2014). Adenosine Deaminase Acting on RNA-1 (ADAR1) Inhibits HIV-1 Replication in Human Alveolar Macrophages. PLoS One 9, e108476.

Weiss, R.A. (1993). How does HIV cause AIDS? Science 260, 1273-1279.

Wong, S.K., and Lazinski, D.W. (2002). Replicating hepatitis delta virus RNA is edited in the nucleus by the small form of ADAR1. Proc. Natl. Acad. Sci. U.S.A. 99, 15118-15123.

Zahn, R.C., Schelp, I., Utermohlen, O., and von Laer, D. (2007). A-to-G hypermutation in the genome of lymphocytic choriomeningitis virus. J. Virol. 81, 457-464.

Zhang, Z., and Carmichael, G.G. (2001). The fate of dsRNA in the nucleus: a p54(nrb)-containing complex mediates the nuclear retention of promiscuously A-to-I edited RNAs. Cell 106, 465-475. 


\section{Microbiology / Molecular Biology}

Caister Academic Press is a leading academic publisher of advanced texts in microbiology, molecular biology and medical research. Full details of all our publications at caister.com

- Cyanobacteria: Omics and Manipulation Edited by: DA Los (2017) www.caister.com/cyano3

- Brain-eating Amoebae: Biology and Pathogenesis of Naegleria fowleri

Author: R Siddiqui, IKM Ali, JR Cope, et al. (2016)

"explains the current knowledge and research" (ProtoView) www.caister.com/naegleria

- Foot and Mouth Disease Virus: Current Research and Emerging Trends

Edited by: F Sobrino, E Domingo (2017)

www.caister.com/fmdv

- Staphylococcus: Genetics and Physiology

Edited by: GA Somerville (2016)

www.caister.com/staph2

- Chloroplasts: Current Research and Future Trends Edited by: H Kirchhoff (2016)

www.caister.com/chloroplasts

- Microbial Biodegradation: From Omics to Function and Application

Edited by: J Długoński (2016)

www.caister.com/biodegradation

- Influenza: Current Research

Edited by: Q Wang, YJ Tao (2016)

www.caister.com/flu3

- MALDI-TOF Mass Spectrometry in Microbiology Edited by: M Kostrzewa, S Schubert (2016)

www.caister.com/malditof

- Aspergillus and Penicillium in the Post-genomic Era Edited by: RP Vries, IB Gelber, MR Andersen (2016)

"new and well-presented book" (IMA Fungus)

www.caister.com/aspergillus2

- The Bacteriocins: Current Knowledge and Future

Prospects

Edited by: RL Dorit, SM Roy, MA Riley (2016)

www.caister.com/bacteriocins

- Omics in Plant Disease Resistance

Edited by: V Bhadauria (2016)

"essential reading ... highly recommended" (Biotechnol. Agron.

Soc. Environ.)

www.caister.com/opdr

- Acidophiles: Life in Extremely Acidic Environments

Edited by: R Quatrini, DB Johnson (2016)

"Contributors from a wide range of biological and environmental sciences" (ProtoView)

www.caister.com/acidophiles
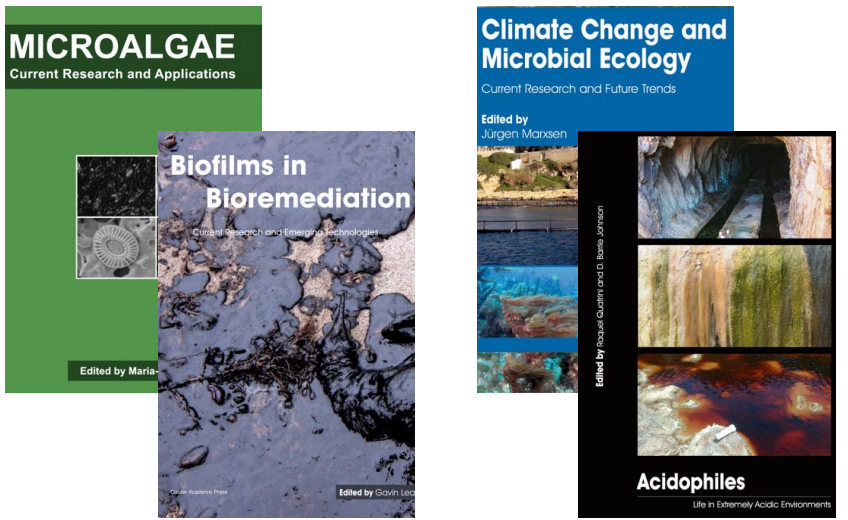
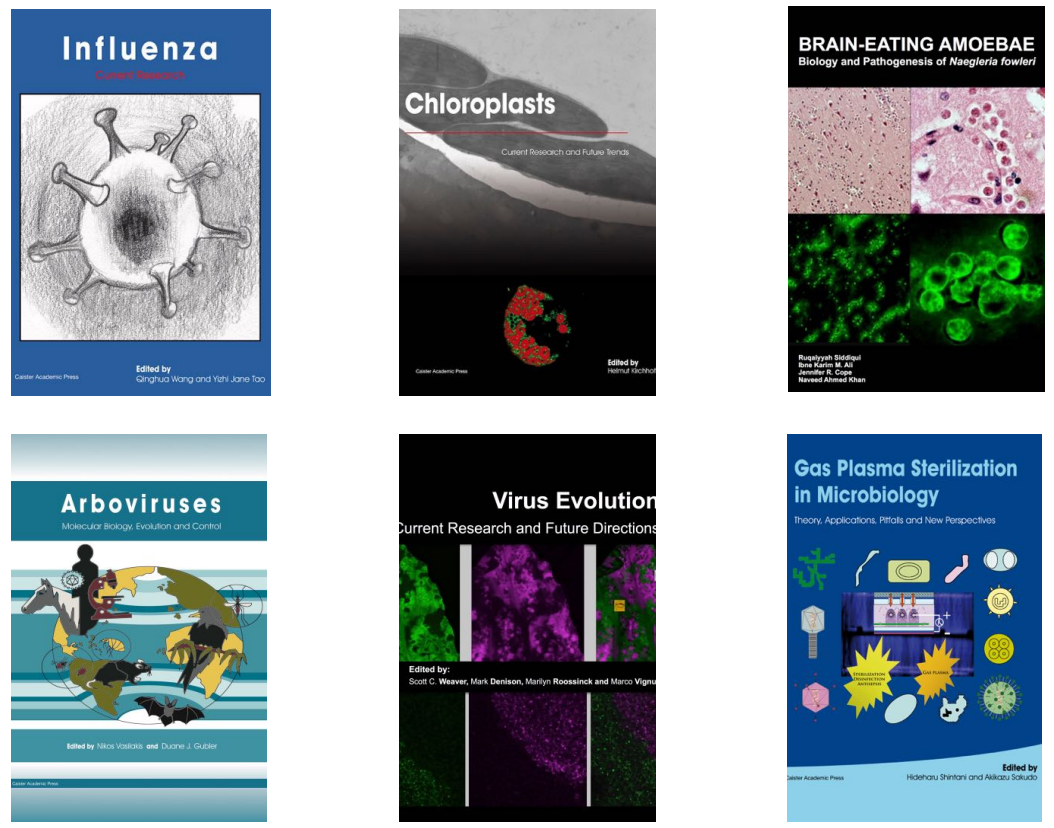

- Climate Change and Microbial Ecology: Current Research and Future Trends

Edited by: J Marxsen (2016)

"impressive" (ASM: Small Things Considered); "written at a high scientific level" (BioSpektrum)

www.caister.com/climate

- Biofilms in Bioremediation: Current Research and Emerging Technologies

Edited by: G Lear (2016)

"describes explicitly the role of biofilms in bioremediation" (Biospektrum); indispensable ... recommended (Biotechnol. Agron. Soc. Environ.) www.caister.com/biorem

- Microalgae: Current Research and Applications

Edited by: MN Tsaloglou (2016)

www.caister.com/microalgae

- Gas Plasma Sterilization in Microbiology: Theory, Applications, Pitfalls and New Perspectives

Edited by: H Shintani, A Sakudo (2016)

"a nice state of the art compilation" (Doodys)

www.caister.com/gasplasma

- Virus Evolution: Current Research and Future Directions Edited by: SC Weaver, M Denison, M Roossinck, et al. (2016) "highly informative ... a pleasure to read" (Microbiol. Today) www.caister.com/virusevol

- Arboviruses: Molecular Biology, Evolution and Control Edited by: N Vasilakis, DJ Gubler (2016)

"a thorough and compelling review ... an outstanding book ... highly recommended" (Am. J. Trop. Med. Hyg.) www.caister.com/arbo

- Shigella: Molecular and Cellular Biology

Edited by: WD Picking, WL Picking (2016)

www.caister.com/shigella

- Aquatic Biofilms: Ecology, Water Quality and Wastewater Treatment

Edited by: AM Romaní, H Guasch, MD Balaguer (2016)

"essential reference book" (Biotechnol. Agron. Soc. Environ.)

www.caister.com/aquaticbiofilms

- Alphaviruses: Current Biology

Edited by: S Mahalingam, L Herrero, B Herring (2016)

"up-to-date review of the field" (Aus. Vet. J.)

www.caister.com/alpha 